
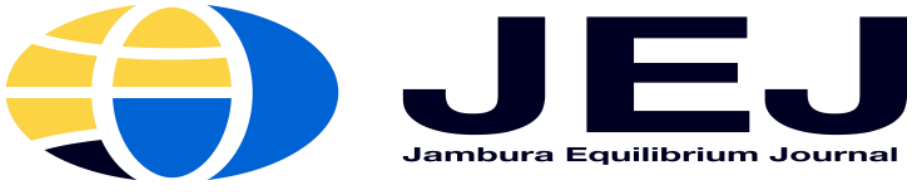

Volume 2. Issue 1. January 2020

P-ISSN 2655-9110

E-ISSN 2656-0445

http://ejurnal.ung.ac.id/index.php/equij

\title{
The Impact of Per Capita Income and Labour Absorption toward Poverty Level in Gorontalo Province
}

\author{
Nelvi Oktaviani R. Gobel ${ }^{1}$, Sri Endang Saleh ${ }^{2}$ \\ Faculty of Economics, Gorontalo State University ${ }^{1,2}$
}

Abstract. This research aims to investigate the impact of per capita income and labour absorption toward poverty level in Gorontalo Province during 2012-2017. This research uses time-series data model from secondary datasets that is obtained from Central Statistics Bureau (Badan Pusat Statistik, BPS). Main findings of this research shows that per capita income has negative impact on poverty level in Gorontalo province while labour absorption has positive impact on poverty level in Gorontalo Province.

\section{Keywords: Poverty; Per Capita Income; Labor Absorption}

Poverty is a complex problem that has never escaped the attention of the government of a country in any part of the world. Poverty may become a major problem in economic development for developing countries like Indonesia.

Poverty has various concepts. The poverty line value that is used to determine poverty refers to the minimum needs needed by someone which is 2100 calories per capita per day, plus the minimum noneating needs which are a person's basic needs which include boards, clothing, schools, transportation, as well as household and other individual needs (BPS, 2017).
BPS further define poverty based on the poverty line. A person or an individual whose expenditure is lower than the poverty line then the person or the individual is referred as the poor. While poverty according to BAPPENAS (2004) is a condition where a person or group people, who are unable to fulfill their basic needs to maintain and develop a dignified life. These basic human needs include the fulfillment of food, clothing, health, education, employment, housing, clean water, land, natural resources and the environment, security from the treatment or threat of violence and the right to participate in social and political life. 
Learning the importance of poverty, this research further focuses on Gorontalo Province. Gorontalo Province became the main object in this research because
Gorontalo is categorized as the fourth province with highest amount of the poor (BPS, 2016). Percentage of people living in poverty in Gorontalo is shown on Figure 1.

Figure 1. Percentage of People Living in Poverty in Gorontalo 2013-2017

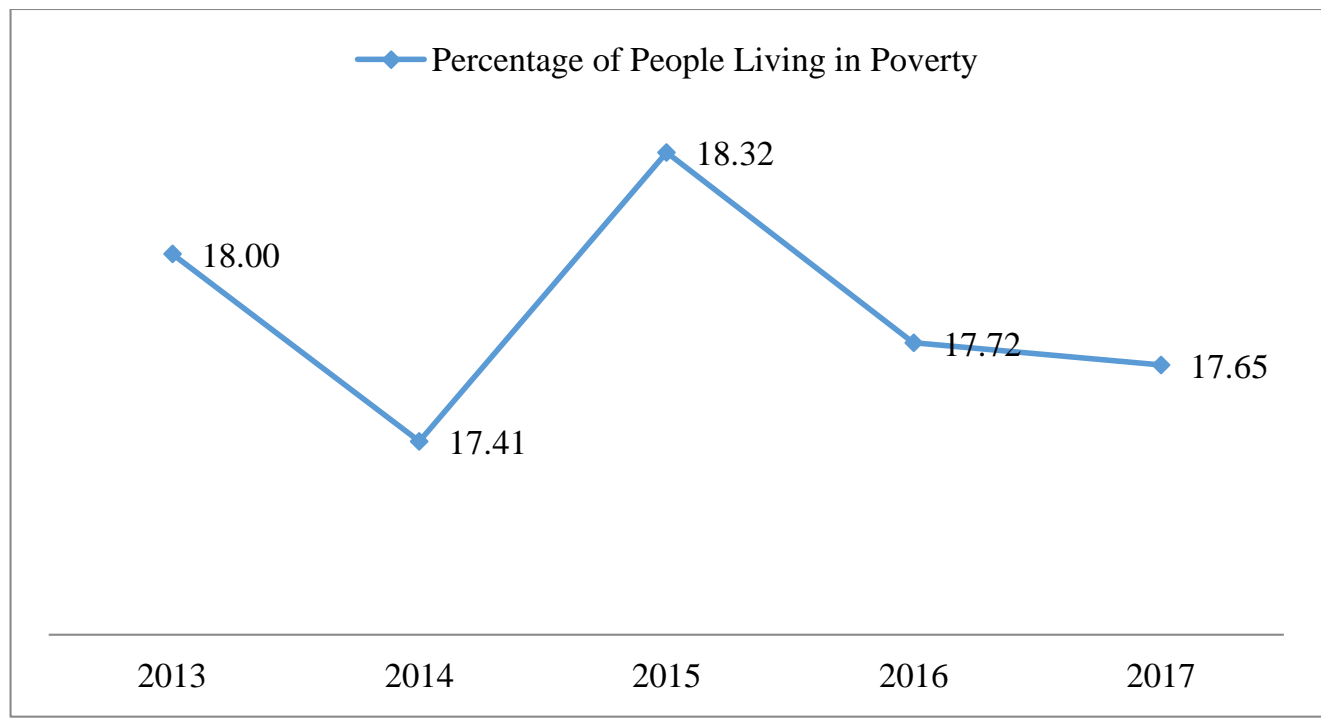

Source: BPS, 2018

The percentage of people living in poverty in Gorontalo fluctuates from 2013 to 2017. However, the poverty rates are relatively higher, because it reaches 17.65 percent in 2017. This seems to be concerning, because it is necessary to start identifying the factors that may affect poverty levels in local level so that it can be used as a reference for districts or cities as efforts to reduce poverty. Many factors affect the level of prosperity of the community. One of the most important factors is the income earned by the community, thus per capita income can be used as a rough gauge of the level of prosperity achieved by the population of a country (Sukirno, 2006).

One element that determines the prosperity of a society is the level of income. Per capita income reaches a its maximum point if conditions of the full employment level are realized, otherwise unemployment will occur. The side effect of unemployment is the decrease of income level, thus it has domino effect in reducing the level of wealth. Lower wealth level due 
to unemployment will lead to poverty trap and associate the economic development into more complex problems (Sukirno, 2010). Therefore, we need to understand the factors that can be considered in efforts to reduce poverty.

Based on the explanation above, this research would like to investigate factors that will impact poverty to further determine poverty alleviation strategies as recommendation. This research focuses on per capita income and labour absorption as main factors that may impact poverty rate in Gorontalo Province.

\section{LITERATURE REVIEW}

Previous studies have analysed the impact of economic indicators on poverty rate. Setiawati (2017) finds that labour absorption has positive and insignificant impact on poverty rate. Zebua et al. (2015) finds that years of schooling and life expectancy rate has significant impact on poverty, while labour and per capita income seems to have no significant effect.

Furthermore, Rasyadi (2011) also found that labour absorption has no significant impact on poverty, as well as the findings of Saputra et al. (2011).

According to previous studies, this research develop conceptual framework in estimating the impact of per capita income and labour absorption on poverty level. Firstly, poverty level is influenced by economic growth, economic growth in the region can be seen through the GRDP growth rate, the higher the GRDP level indicates that the region is prosperous which means the poverty level in the area is low.

Increasing the absorption of labour as capital for regional development will be a way to reduce the level of poverty that occurs. Low labour productivity may result in poverty. Thus, poverty is not solely caused by unemployment, many poor families have an income, even fixed income but included in the category of poor because their income is very low which is influenced by their low work productivity. Therefore, in addition to the income factor, labour productivity is also very relevant in influencing poverty levels. Based on the description above, this study refers to poverty levels.

This research will use per capita income and labour absorption as main independent variables that impact poverty rate in Gorontalo Province. 


\section{RESEARCH METHODOLOGY}

This research aims to analyse the impact of per capita income and labour absorption on poverty rate in Gorontalo Province. This research uses quantitative method and uses datasets obtained from BPS. This research further applies panel data regression.

\section{Regression Model}

This research uses two main independent variables, which is the per capita income that is measured with Gross Regional Domestic Product (GRDP) and Labour Absorption Level and Poverty Rate as the dependent variable. Panel Data Regression Model is written in Equation 1 as follows:

$$
\begin{gathered}
\text { Poverty }_{i, t}=\alpha_{0}+\alpha_{1} P P_{i, t}+\alpha_{2} T K_{i, t}+ \\
\varepsilon_{i, t} \text { (1) }
\end{gathered}
$$

where Poverty i,t is poverty rate of regencies $i$ during period $t ; P P_{i, t}$ is income per capita income of regencies $i$ during period $t$; $T K_{i, t}$ is labour absorption level of regencies $i$ during period $t$.

\section{RESULTS AND DISCUSSION}

Regression results are shown in Table 1. According to the regression model, the empirical model are as follows:

$$
\begin{gathered}
\text { Poverty }_{i, t}=2.764-0.144 P P_{i, t}+ \\
0.371 T K_{i, t}+\varepsilon_{i, t} \quad \text { (2) }
\end{gathered}
$$

The empirical results show that the average poverty rate is fixed at 2.764 during 2012-2017, if other factors were ignored or ceteris paribus. Moreover, the empirical results show that there is negative impact of per capita income on poverty rate, where one percent increase of per capita income may reduce poverty rate by 0.144 percent. Labour absorption has positive impact on poverty rate, where one percent increase of labour absorption rate, poverty rate will increase by 0.144 percent.

Furthermore, the adjusted R-Square shows that the model can explain $97.19 \%$ the dependent variable, which means that both per capita income and labour absorption level has the ability to explain poverty rate in Gorontalo Province.

\section{The Impact of Per Capita Income on} Poverty Rate in Gorontalo 2012-2017

Regression test results show that per capita income has a negative and significant effect on poverty levels in Gorontalo Province for the period 2012-2017. The regression coefficient, which is negative, shows that when the variable income per capita gets bigger, it becomes a picture that every population has the ability to meet their economic needs, so this is a sign of a reduction in poverty levels in Gorontalo Province. Hence, according to the results, 
government needs to strive to increase per capita income by increasing investment in the area which has implications for the maximum absorption of labour, so that the community will have a larger income level that implies the fulfilment of basic needs.

If the GRDP per capita increases, the population in the region becomes more prosperous or if the GRDP per capita increases, the poverty level will also decrease. Also, another thing that will support a higher rate of economic growth is to reduce poverty more quickly and accurately. This study is also in accordance with research conducted by Whisnu (2011) that stated higher GRDP leads to the decrease of the poverty level.

This negative result is also found by by Rika S (2012), that even though the level of income has reached the level of minimum basic needs, but it is still small compared to the level of income of the surrounding community, the person or household is still in a poor state. This concept is further referred to as relative poverty.

Poverty is relatively related to development problems that are structural in nature, namely unequal policies that cause unequal distribution of income. The problem of income distribution or poverty is relatively closely related to the problem of absolute poverty because absolute poverty is a result of inequality in income distribution. If the income gap is high then the number of poor people will be high. Relative poverty will always arise as long as there is an imbalance in income distribution.

The test results in this research are in essential in supporting several previous scientific studies such as that conducted by Saputra and Mudakir (2011) that also shows GRDP has significant and negative impact on poverty.

\section{The Impact of Labour Absorption Rate on Poverty Rate in Gorontalo 2012-2017}

The empirical results shows that he labour absorption rate has a positive and significant effect on poverty levels in Gorontalo Province in the period 20122017. This result implies that first, the domination of productive age population will not affect the number of poor people, because the number of workers absorbed in rural areas is much higher than in urban areas for low levels of education this is due to workers in rural areas, especially in the agricultural sector and informal education does not require special education. This proves that a high Labour Force Participation Rate (TPAK) has no 
significant affect on the number of poor people.

Secondly, the TPAK is not only seen from the regional sector but from the gender sector the female TPAK tends to be lower than the male TPAK because this is due to the large number of women who choose as a non-workforce group, among others, housewives. Because many women choose to become non-workforce, the labour force participation rate does not affect poverty in Gorontalo Province.

The number of labour force employed is a picture of the condition of available employment. The greater the number of available jobs, the greater the total production in an area. So that the percentage of poverty in the area will decrease.

This further implies that if someone is in a state of unemployment means he does not get extra income to meet their needs. It can be seen that if a person is unemployed it will make him look poor because he cannot fulfil basic needs in his daily life. Therefore, optimizing the absorption of labour will encourage the higher income level of the people to satisfy their basic needs.
In general, the empirical results found that per capita income and labour absorption had a significant effect on the level of poverty in Gorontalo Province in the period 2012-2017. This result is in accordance with the theory of trickle-down effect according to Kuncoro (2007) which explains that the progress made by a group of people will automatically trickle down to create jobs, employment, and various economic opportunities which in turn will foster various conditions for the creation of distribution equitable economic growth results.

\section{CONCLUSION}

This research was conducted to analyse the impact of per capita income and labour absorption rate on poverty level in Gorontalo Province 2012-2017. Based on the results and discussion, this research concludes that per capita income has negative and significant impact on poverty, while labour absorption rate has positive and significant impact on poverty. Therefore, this research recommends government to increase investments to boost per capita income and create mor jobs to increase labour absorption. 


\section{REFERENCES}

Arsyad,Lincolin (2005) "Pengantar Perencanaan Pembangunan Ekonomi” Yogyakarta.

Anwar Rasyadi (2011) "Pengaruh Produk Domestic Bruto (PDB) Dan Tingkat Partisipasi Angkatan Kerja (TPAK) Terhadap Kemiskinan Indonesia”.Skripsi

Badan Pusat Statistik "Informasi Jumlah Penduduk Miskin 20122017" Di Provinsi Gorontalo

Badan Pusat Statistik "Informasi Pendapatan Perkapita 20122017” Di Provinsi Gorontalo

Badan Pusat Statisti "Informasi Tingkat Partisipasi Angkatan Kerja 2012-2017” Di Provinsi Gorontalo

Caraka (2011.) Analisis Regresi Dan Uji Asumsi Regresi Linear Statistika.Universitas Diponegoro.Semarang

Ekananda Mahyus (2014) " Analisis Data Time Series" Penerbit Mitra Wacana Media. Jakarta

Gustav.F (1987) "Ekonomi Indonesia" Jakarta : Gramedia

Gujarati,2010. Dasar-Dasar Ekonometrika.Jakarta.Erlangga

Hernanto, Teori Pendapatan Perkapita, Jakarta : Erlangga 1994

Setiawati Irmawati (2017) "Pengaruh Produk Domestik Regional Bruto,Pendidikan Dan Tenaga Kerja Terhadap Tingkat Kemiskinan Di Kabupaten
Pinrang”. Skripsi.Fe. Universitas Islam Negeri Alauddin Makassar.

Latumaerissa, R. J. (2015) Perekonomian Indonesia dan Dinamika Ekonomi Global. Jakarta. Mitra Wacana Media.

Mulyadi S, Ekonomi Sumber Daya Manusia Dalam Perspektif Pembangunan, Jakarta Pt Grafindo Persada 2003

Moh.Kurniawan.DP (2017).Analisis Faktor-faktor Penyebab Kemiskinan Di Kabupaten Musi Banyuasin (studi kasus dikecamatan sungai lilin). Jurnal Ilmiah Ekonomi Global Masa Kini.FE, Universitas Indo Global Mandiri.

Sukirno,Sadono (2006). Mikro Ekonomi, Teori Pengantar. Edisi Ketiga .Jakarta.Raja Grafindo Persada. Jakarta

Sugiyono, 2014. Metode Penelitian Pendidikan Pendekatan Kuantitatif, Kualitatif Dan R\&D Bandung Alfabeta.

Soebagiyo, Daryono. 2013. Perekonomian Indonesia. Surakarta: Universitas Muhammadiyah Surakarta.

Rusdarti Dan Lesta Karolina Sebayang. (2013). Faktor-Faktor Yang Mempengaruhi Tingkat Kemiskinan Di Provinsi Jawa Tengah. Jurnal Economi

Soemantri,Anting. (2006). Aplikasi Statistika Dalam Penelitian. Bandung : Pustaka Setia. 
Todaro, Michael P. Dan Stephen C. S. (2000). Pembangunan Ekonomi Di Dunia Ketiga Edisi Ketujuh. Jakarta: Erlangga.

Widya Ningsih Zebua Djaimi Bakce Dan Syaiful Hadi (2015 )" Analisis Faktor-Faktor Dominan Yang Mempengaruhi Kemiskinan Di Provinsi Riau". Jurnal

Whisnu Adhi Saputra Drs. Y Bagio Mudakir Msp (2011) Analisis Pengaruh Jumlah Penduduk PDRB,IPM Pengangguran
Terhadap Kemiskinan Di Kabupaten/Kota Jawa Tengah. Skripsi. 